\title{
Abstracts of symposium contributions not submitted for publication
}

\author{
Tectonic evolution of the Dalradian terrane (abstract)
}

\section{R. Anderton}

The Dalradian rocks of Scotland and Ireland were deposited as a result of the stretching and thinning of their underlying continental basement and were deformed and metamorphosed by the shortening and thickening of the resulting basement-cover pile. As to a first approximation, the stretching can be viewed as part of a worldwide episode of continental rifting that broke up the Proterozoic supercontinent at about the Precambrian-Cambrian boundary. The shortening episode was the result of the convergence of an island-arc or microcontinental plate, towards the end of the Cambrian.

In trying to consider these processes in more detail, one is confronted by two major problems; the lack of good control on the timing of events affecting the Dalradian rocks and the fact that the boundaries of the terrane are often tectonic. Evolution of the Dalradian terrane has, therefore, to be considered in isolation from adjacent terranes until age dating and palaeomagnetism can pin down the relationships during the late Precambrian and Cambrian between the bit of crust now represented by the Dalradian Supergroup, and the Midland Valley, the Southern Uplands and NW Scotland.

Notwithstanding these problems, it is possible to construct a model for the tectonic evolution of the Dalradian terrane. This envisages it as lying in an area of weak, recently tectonised crust between the Baltic and N Atlantic cratons in late Precambrian times. The model involves slow thinning of this crust which gave way to more rapid stretching, resulting in faulting and rapid subsidence, near the end of the Precambrian. Small ocean basins developed and were aborted before the Baltic plate wrenched itself free from the supercontinent. The Dalradian terrane then thermally subsided and became a starved continental margin. This margin was subsequently compressed by the convergence of either a microcontinental plate or an island-arc towards the $\mathrm{N}$ Atlantic craton in late Cambrian times. The main uplift and denudation of the resulting metasedimentary pile must have been completed during the Ordovician, well before the subsequent uplift associated with the intrusion of the Newer granites.

R. ANDERTON, Department of Applied Geology, Strathclyde University, Glasgow G1 1XJ, Scotland.

\section{Sr and Nd isotope evidence for age and origin of crustal xenoliths from the Midland Valley of Scotland and central Ireland (abstract)}

\section{G. R. Davies, B. G. J. Upton and P. Strogen}

We report a combined REE, Rb-Sr and Sm-Nd isotope study of lower crustal xenoliths from the Midland Valley of Scotland and central Ireland with the aim of establishing the age and petrogenesis of the lower crust in these regions.

Metagabbroic basic granulites from Hawk's Nib define a Sm-Nd errorchron of $574 \pm 137$ Ma (MSWD = 3.8) with an initial ratio equivalent to $\mathrm{E} \mathrm{Nd}$ of $+3 \cdot 7$. Quartzofeldspathic and pyroxene granulites from Partan Craig have similar Sm-Nd and $\mathrm{Rb}-\mathrm{Sr}$ isotope systematics to those of Hawk's Nib but show no isochronous relationships.

Garnet granulites from Partan Craig have a metasedimentary origin and yield an Rb-Sr whole-rock age of $1101 \pm 63 \mathrm{Ma}$ (MSWD = 8). Significantly Sm-Nd model ages are c. $1100 \mathrm{Ma}$. Meta-igneous garnet granulites from County Westmeath have $\mathrm{Nd}$ and $\mathrm{Sr}$ model ages of $c .1000 \mathrm{Ma}$. From consideration of the $\mathrm{Sm}-\mathrm{Nd}$ and $\mathrm{Rb}-\mathrm{Sr}$ isotope systematics of both garnet granulite suites, it is argued that the 1000-1100 Ma ages do not represent mixing relationships and that lower crust with products of the Grenvillian orogeny exist beneath the Midland Valley of Scotland and central Ireland.

Finally, it is argued that xenoliths of lower crustal material formed in the Grenvillian and late Precambrian episodes may represent the crustal components involved in the petrogenesis of both the pre- and post-tectonic Caledonian granites of central Scotland. There is no evidence of Archaean crust beneath the Midland Valley.

G. R. DAVIES, Department of Earth Sciences, Open University, Walton Hall, Milton Keynes MK 76AA, England.

B. G. J. UPTON, Grant Institute of Geology, University of Edinburgh, West Mains Road, Edinburgh EH92JW, Scotland.

P. STROGEN, Department of Geology, Trinity College, Dublin 2, Republic of Ireland.

\section{Geophysical models for the Southern Uplands (abstract)}

\section{R. G. Hipkin and M. Warner}

Gravimetrically determined outcrop densities confirm the conventional view of gross lithological uniformity and continuity in the Southern Uplands, extending from Armagh to Berwickshire, and also confirm the sharp boundaries to the $\mathbf{N}$ and $\mathrm{S}$ at the Southern Uplands fault and the Northumberland and Solway basins. However, this picture is superficial and misleading. The Southern Uplands fault is not a major break in crustal structure: in northern Britain, the only outstanding break in Bouguer anomaly pattern occurs within the Grampian Highlands. There is comparative uniformity from Loch Tay to the Tyne. The Southern Uplands fault has only locally a large normal throw and its geometry precludes at least post-Silurian strike-slip displacement.

Within the Southern Uplands, the systematic variation in the style and trend of gravity and magnetic anomalies, both along 
and across strike, argues strongly against a thick sedimentary wedge model extrapolating the uniform surface geology to lower crustal depths. Detailed analysis of the Tweeddale gravity low implies density contrasts at only $1-2 \mathrm{~km}$ depth both near its axis and its southern flank.

In contrast to the widely publicised initial interpretation of the LISPB seismic profile, a refraction study shows that along-strike seismic velocities appropriate to metamorphic basement and inconsistent with greywackes also occur within 1-2 km of the surface along the whole $120 \mathrm{~km}$ of a profile from Kirkonnel to Dunbar. This confirms the indications of earlier published work of shallow high velocities, while other recent work shows that LISPB is not inconsistent with these data. It is also premature to erect vast tectonic edifices upon the supposed difference between $6.4 \mathrm{~km} \mathrm{~s}^{-1}$ basement in the $\mathrm{N}$ and $6 \cdot 3 \mathrm{~km} \mathrm{~s}$ in the $S$.

Structural models which integrate the results of seismic, gravity and magnetic studies are presented involving pre-Caledonian and Caledonian granite plutons, and continental basement blocks and slivers. A simple rheological model is suggested to account for the varied development of the Southern Uplands fault and adjacent marginal basins, and predictions are made about the ability of seismic reflection lines to detect the fault and underlying suture.

R. G. HIPKIN, Department of Geophysics, University of Edinburgh, King's Buildings, West Mains Road, Edinburgh, EH9 3JW, Scotland.

M. WARNER, Bullard Laboratories, University of Cambridge, Madingley Rise, Madingley Road, Cambridge CB3 DEZ, England.

\section{Evolution of the Ballantrae complex: evidence from the Downan-Currarie terrane and ana- logues from the SW Japan active margin (abstract)}

\section{J. K. Leggett, T. J. Barrett, Y. Ogawa and A. H. F. Robertson}

The Currarie complex, an ophiolitic olistostrome unit $>100 \mathrm{~m}$ thick, is in fault contact with the Downan tract, the southernmost mafic sequence of the Ballantrae complex. It comprises composite polymictic debris-flow conglomerates. The clasts are predominantly basaltic (massive, pillowed, brecciated; phyric and aphyric) and pelagic (jasper, radiolarian chert) and up to several metres across, in some cases possibly much more. They are set in a hemipelagic matrix made largely of red siliceous mudstone. The complex provides critical clues to the relationship between the Ballantrae complex and the younger greywacke-dominated Southern Uplands accretionary terrane to the S. Most of the clasts appear to be derived from a Downan-type sequence. A $N$. gracilis Zone (late Llandeilo-early Caradoc) fauna from a graptolitic band in the matrix (originally reported by B. N. Peach and J. Horne and recollected during this study) may indicate that the Downan sequence is significantly younger than the main part of the Ballantrae complex (the mafic sequences of which are dated as Arenig by graptolite faunas in intercalated pelagic sediments, and the emplacement of which against the Laurentian continental margin is dated as Arenig by radiometric means). Since the northernmost greywackes of the Southern Uplands accretionary terrane are of gracilis age, and the earliest of the supra-ophiolitic slope-shelf-paralic sediments (in the Stinchar Valley) are of Llanvirn age, it is clear that either or both of the Stinchar and Dove Cove faults (northern and southern margins of the Downan tract) are sites of appreciable 'missing stratigraphy'. Following regional arguments for continuous northward subduction throughout Ordovician time under Scotland, we favour for pre-gracilis times a model involving episodic accretion of large ophiolitic bodies, of probable seamount origin, during an overall regime of subduction erosion or of strike-slip removal of outer fore-arc elements.

Greywacke beds intercalated in the siliceous mudstone matrix of the Currarie complex show slump fold features, and phacoidal clasts of jasper, radiolarian chert and greywacke in the debris flows show evidence of extension and soft-sediment deformation prior to thrusting and shearing. This we interpret as the result of seamount collapse on an outer trench wall, and intercalation of seamount-derived matrix and blocks in a trench clastic succession prior to accretion. Currarie complex associations crop out in other places to the $S$ of Currarie in the Glen App terrane.

Analogous examples of seamount collapse and accretion are abundant in Japan: for example, the modern Daiiti-Kasima seamount in the modern Japan Trench, and the Late Palaeozoic-Mesozoic Sawadani ophiolite of the Chichibu terrane behind the Cretaceous-Palaeogene Shimanto accretionary terrane.

J. K. LEGGETT, Department of Geology, Imperial College of Science and Technology, London SW7 2BP, England.

T. J. BARRETT, Department of Geology, University of Toronto, Toronto, Canada M5S 1A1.

Y. OGAWA, Department of Earth Sciences, Nihon University, Sakurajosui, Tokyo.

A. H. F. ROBERTSON, Grant Institute of Geology, University of Edinburgh, West Mains Road, Edinburgh EH9 3JW, Scotland.

\section{Isotopic evidence for mantle heterogeneity beneath the Midland Valley and adjacent regions from studies of inclusion suites (abstract)}

\section{A. Menzies and A. N. Halliday}

Preliminary determinations of the isotopic compositions of $\mathrm{Sr}$ and $\mathrm{Nd}$ in ultramafic nodules and their host Scottish Carboniferous volcanic rocks are presented. The ultramafic nodules are considered to represent fragments of mantle wallrock and disrupted mantle vein systems and they exhibit a considerable range in $\mathrm{Sr}$ and Nd isotopic composition. The present day ${ }^{87} \mathrm{Sr} /{ }^{86} \mathrm{Sr}$ and ${ }^{143} \mathrm{Nd} /{ }^{144} \mathrm{Nd}$ of the nodules range from 0.7042 to 0.7076 and from 0.51271 to 0.51183 , respectively. Similarly the lavas exhibit a spread of 0.7037 to 0.7087 in ${ }^{87} \mathrm{Sr} /{ }^{86} \mathrm{Sr}$ and 0.51272 to 0.51231 in ${ }^{143} \mathrm{Nd} /{ }^{144} \mathrm{Nd}$. Although these data are limited and not age corrected, they are sufficient to note some interesting observations and draw general conclusions. The Midland Valley lavas have less radiogenic $\mathrm{Sr}\left({ }^{87} \mathrm{Sr}{ }^{86} \mathrm{Sr} 0.7037-0.7058\right)$ than those of the Scottish Highlands and Outer Hebrides $(0.7060-0.7087)$. This pattern is also observed in the nodules. The lavas and nodules of the Highlands and Outer Hebrides have less radiogenic Nd than those of the Midland Valley. Data for Loch Roag (Outer Hebrides) define a near-vertical vector on a $\mathrm{Nd}-\mathrm{Sr}$ isotopic plot, similar to that displayed by potassic volcanic rocks from the Leucite Hills, U.S.A., and apatite-rich nodules 
from eastern Australia. This isotopic characteristic is interpreted as indicating a time-integrated response to an influx of $\mathrm{CO}_{2}$-rich fluid which would tend to have a high content of LREE. With the passage of time, the decrease in $\mathrm{Sm} / \mathrm{Nd}$ ratio would register as a low ${ }^{143} \mathrm{Nd} /{ }^{144} \mathrm{Nd}$ ratio, with little or no change in the ${ }^{87} \mathrm{Sr} /{ }^{86} \mathrm{Sr}$ ratio due to the low $\mathrm{Rb}$ content of the fluid. The Streap mantle xenoliths ( $\mathrm{N}$ Highlands) exhibit a somewhat different variation in isotopes as they lie to the right of the 'mantle array' in a similar sense to island-arc basalts.

The data for the Midland Valley suggest derivation from a source with 'depleted' isotopic characteristics like that observed in most ocean-island basalts. The pattern of higher ${ }^{143} \mathrm{Nd} /{ }^{144} \mathrm{Nd}$ in the Midland Valley than further $\mathrm{N}$ is analogous to that which has been observed for the Old Red Sandstone lavas and the late Caledonian granites. In the latter case, the pattern is due to contamination with differing kinds of basement. Moreover, the $\mathrm{Nd}-\mathrm{Sr}$ data for the Carboniferous volcanic rocks and nodules display some correspondence with the crustal geology which suggests that crustal contamination may be an explanation for the data. However, changes in the age of the subcontinental lithosphere are likely to parallel changes in the age of the continental crust; hence further work is needed to clarify how much of the observed variation reflects mantle heterogeneity.

M. A. MENZIES, Department of Earth Sciences, Open University, Walton Hall, Milton Keynes MK7 6AA, England.

A. N. HALLIDAY, Isotope Geology Unit, Scottish Universities Research and Reactor Centre, East Kilbride, Glasgow G75 0QU, Scotland.

\section{Pre-Carboniferous evolution of the western continuation, in Ireland, of the Midland Valley of Scotland (abstract)}

\section{W. E. A. Phillips, J. R. Graham and J. B. Simon}

Continuity of the geology of the Midland Valley of Scotland into Ireland is shown by Devonian and older rocks; however, the boundaries are no longer defined by the Highland Boundary and Southern Uplands faults, which die out westwards.

Recent work on Lower Old Red Sandstone inliers in Ireland provides evidence for continuing a Highland Boundary fault westwards with diminishing throw along a line well $S$ of the conventional extrapolation to Clew Bay. There is no evidence for a contemporary continuation of the Southern Uplands fault.

Similarities exist between the Silurian rocks of Mayo and those of the Midland Valley; however, the northern marginal marine and volcanic facies in Mayo is controlled by a branch of the Great Glen fault system in Clew Bay. There is no evidence for a southern land mass (Cockburnland) continuing into Ireland.

Evidence for an island-arc complex of early Ordovician age in the Midland Valley is supported by the more extensive outcrops of such rocks in the northern part of the Tyrone igneous complex, at Charlestown and further $\mathrm{W}$ in the Tourmakeady-Lough Nafooey area of Mayo. Recent work in Connemara suggests that part of this arc may be seen again in the Delaney dome of S Connemara. The southern part of the Tyrone igneous complex probably represents a high-level section through an ophiolite complex which has been thrust northwards, as at Ballantrae. The misnamed 'South Mayo Trough' represents the northwesterly edge of the arc and its fore-arc basin. The change in strain in the Dalradian rocks to the $\mathrm{N}$, with dextral transcurrent strains in N Mayo being replaced by southward overthrusting in Tyrone and Scotland, may explain the easterly convergence of the main arc and Dalradian outcrops. It is suggested that the arc has been partly overridden by the Dalradian rocks leading to Buchan-type metamorphism and basic magmatism in NE Scotland and in Connemara.

The anomalous southerly position of the 'Perthshire facies' Dalradian sediments in Connemara is most simply explained by sinistral displacement from the $\mathrm{W}$ in the Ordovician, combined with a component of southerly thrusting over the volcanic arc sequence of the Delaney dome in S Connemara.

Recent aeromagnetic data shows continuity of highly magnetic crust eastwards from S Connemara beneath much of the Longford-Down zone of central Ireland. It appears therefore that the Llanvirn-Wenlock sediments of the Longford-Down zone, with their remarkable recumbent structures, have been thrust over the 'Midland Valley arc system' in Ireland. Continuity of Midland Valley crust southwards to the Iapetus suture in Ireland is also suggested by the presence of granulite xenoliths, of Ox Mountain type, in Carboniferous volcanic rocks in the Longford-Down zone. Structural and geophysical evidence suggest that the Iapetus suture in central Ireland dips at a low angle to the S. This could explain the development of larger-scale northward thrusting of accretive prism rocks of the Longford-Down zone over Midland Valley basement.

W. E. A. PHILLIPS, J. R. GRAHAM and J. B. SIMON, Department of Geology, Trinity College, Dublin 2, Republic of Ireland.

\section{Sources of Old Red Sandstone lavas in the Midland Valley and adjacent regions (abstract)}

\section{F. Thirlwall}

The use of isotope and trace-element parameters of igneous rocks to provide information on the underlying mantle and crust is a process fraught with difficulties. These arise from the problem of distinguishing between incompatible element-enriched signatures produced in the crust, in the mantle or in mantle modified by subducted crust. Distinction between these sources of enrichment may sometimes be made through detailed studies of rock suites, including analyses for several different isotopic systems and for both major and trace-elements.

Basalts and basic andesites rich in $\mathrm{Mg}$, Ni and $\mathrm{Cr}$ from the Scottish Old Red Sandstone must be mantle-derived, although all have undergone minor fractional crystallisation during ascent. In the SW Highlands these have high incompatible element concentrations and $\mathrm{Sr}-\mathrm{Nd}$ isotopic compositions close to or slightly less radiogenic than the estimated bulk earth composition, coupled with mildly unradiogenic $\mathrm{Pb}\left({ }^{206} \mathrm{~Pb} /{ }^{204} \mathrm{~Pb}=17-18\right)$. No correlations exist with fractionation indices, and the data are consistent with derivation from a mildly enriched subcontinental mantle source. In contrast, in the Midland Valley, $\mathrm{Sr}-\mathrm{Nd}$ isotopic compositions of basalts and andesites fall on a trajectory between depleted MORB-source mantle and upper crustal compositions, although rare examples fall close to the SW Highland lavas. Increasingly 'crustal' Sr-Nd isotopes are accompanied by increasing $\mathrm{SiO}_{2}$ and increasing enrichment in LREE, $\mathrm{Rb}, \mathrm{K}, \mathrm{Pb}$ and $\mathrm{U}$, correlations which may be accounted for by some mixing process between a MORB-source component and Lower Palaeozoic greywackes such as those exposed in 
the Southern Uplands. Low-Mg basalts and basic andesites have identical isotopic compositions to more primitive ones with the same $\mathrm{SiO}_{2}$, implying that fractionation has occurred after incorporation of the crustal component. Consideration of the chemical composition and possible thickness of Lower Palaeozoic rocks in the Midland Valley leads to the conclusion that these were incorporated into the mantle source of the lavas by subduction.

A silica gap exists in the Midland Valley (excepting the Pentland Hills) between these basalts and andesites $(<65 \%$ SiO 2$)$ and the much less abundant acidic lavas $(>70 \%)$. These are therefore potential candidates for crustal melts, but throughout the Midland Valley they show a very restricted range of $\mathrm{E}_{\mathrm{Nd}}(410)$ from $+3 \cdot 6$ to $+4 \cdot 6$, contrasting with the range of -2 to +6 for the basalts and andesites. The origin of these acidic magmas is unclear at present, but they provide no evidence for ancient crust beneath the Midland Valley.

M. F. THIRLWALL, Department of Geology, Bedford College, Regents Park, London NW1 4NS, England.

\section{Age and derivation of metamorphic clasts in conglomerates in and around the Midland Valley (abstract)}

\section{O. van Breemen, A. N. Halliday, B. J. Bluck and P. Haughton}

We report $\mathrm{Rb}-\mathrm{Sr}$ mineral--whole-rock dates for muscovites and biotites from metamorphic clasts found in conglomerates in the Silurian of the Southern Uplands and the Old Red Sandstone of the Midland Valley. The dates are highly variable but it is shown that this is a function of the importance of the common $\mathrm{Sr}$ correction and hence an artifact of the technique. The most reliable data define ages of $c .460 \mathrm{Ma}$. This is taken to indicate a time of rapid uplift of a low-grade metamorphic source in the vicinity of the present Midland Valley; c. $460 \mathrm{Ma}$ was also the approximate time of onset of post-tectonic granite plutonism throughout Scotland and thrusting in the Dalradian and Lower Palaeozoic rocks of the Midland Valley equivalent to that in Connemara. This suggests that the rapid uplift was isostatically related to granite injection and thickening of the continental crust by underthrusting.

O. VAN BREEMEN, Geological Survey of Canada, 601 Booth Street, Ottawa, Canada K1A 0E8.

A. N. HALLIDAY, Isotope Geology Unit, Scottish Universities Research and Reactor Centre, East Kilbride, Glasgow, G75 0QU, Scotland. B. J. BLUCK and P. HAUGHTON, Department of Geology, University of Glasgow, Glasgow G12 8QQ, Scotland. 